\title{
The Relationship Between Knowledge, Trust, Intention to Pay Zakah, and Zakah-Paying Behavior
}

\author{
S. Martono ${ }^{1}$, Ahmad Nurkhin $^{1}$, Fatimah Lutfhiyah ${ }^{1}$, Fachrurrozie $^{1}$, Ahmad Rofiq $^{2} \&$ Sumiadji $^{3}$ \\ ${ }^{1}$ Faculty of Economics, Universitas Negeri Semarang, Central Java, Indonesia \\ ${ }^{2}$ Postgraduates, UIN Walisongo, Central Java, Indonesia \\ ${ }^{3}$ Accounting Department, State Polytechnic of Malang, Eat Java, Indonesia \\ Correspondence: S. Martono, Faculty of Economics UNNES, Sekaran Campus, Gunungpati, Semarang, Central Java, \\ Indonesia. Tel: 62-815-654-2956.
}

Received: March 10, 2019

Accepted: March 26, 2019

Online Published: April 7, 2019

doi:10.5430/ijfr.v10n2p75

URL: https://doi.org/10.5430/ijfr.v10n2p75

\begin{abstract}
The purpose of this study is to investigate the effect of knowledge and trust on intention to pay zakah. This study also tests the the effect of knowledge, trust, and intention to pay zakah on zakah-paying behavior. The population of the research comprises the employees of the Ministry of Religion, specifically in the Semarang municipal region. The method of data collection used is a questionnaire which has been developed from those used by previous researchers. Path analysis was used to analyze the data by using warpPls 6.0. The results show that knowledge and trust have a postive and significant effect on the employees' intention to pay zakah and their zakah-paying behavior. Intention to pay zakah has no impact of on zakah-paying behavior. Knowledge has a high positive effect on intention to pay zakah and zakah-paying behavior. This research suggests that zakah organizations should increase their trust by improving their performance and service quality. They should organize education and dissemination activities to improve zakah payers' knowledge.
\end{abstract}

Keywords: knowledge, intention to pay zakah, trust, zakah-paying behavior

\section{Introduction}

Poverty is an important issue that demands attention. One of the efforts made to reduce poverty in Indonesia has been to even out the income inequality between those people who are capable and those who are disadvantaged (Canggih, Fikriyah, \& Yasin, 2017). In Islamic studies, zakah (a kind of tithe) is an instrument of income equalization. Zakah is the third pillar of Islam that must be fulfilled with regard to one's wealth, the provisions of which are regulated by Koran; one of these is the word of God in Surah Al Baqarah verse 43 which reads: "Attend to your prayers, pay your zakah, and bow down before God with those who bow down".

Zakah is wealth that must be spent by Muslims or business entities by giving it to those who have the right to receive it in accordance with Islamic law. Infak is wealth given for general benefit by someone or a business entity aside from zakah. Sadaqah is assets or non-assets handed over by a person or business entity outside of zakah for the general benefit (Zakah Law No.23/2011 pertaining to Management of Zakah).

Payment of zakah is an obligation for a Muslim. Khasanah (2016) explains that zakah serves to redistribute wealth from the rich to the poor according to certain terms and conditions. The assets that are given have the function of cleansing and purifying the soul of its stingy and avaricious nature. Fakhruddin (2016) adds that zakah serves to help others by being channeled to those who are entitled to receive zakah (mustahiq). Thus, paying zakah is an obligation that must be fulfilled properly.

This phenomenon shows that zakah, which has not yet been optimally empowered, still has potential (BAZNAS, 2016). One reason is that there are still many umma (members of the Islamic community) who have not complied in terms of paying zakah, especially professional zakah. This kind of zakah is paid out of income received by someone such as salary, wages, etc.

The factor making acceptance of zakah less than optimal in Indonesia is the lack of trust in institutions that manage zakah. Zakah management institutions in Indonesia are based on Law No.23/2011 pertaining to the Management of 
Zakah, and come in the form of appointed collectors such as BAZNAS (Badan Amil Zakah Nasional or National Zakah Collection Agency), LAZ (Lembaga Amil Zakah or Zakah Collection Institution) and UPZ (Unit Pengumpul Zakah or Zakah Collection Unit). Muslim communities in Indonesia are allowed to pay zakah through any zakah management institution. In reality, no small numbers of zakah management institutions are unprofessional in managing those zakah funds. This has caused public distrust of appointed zakah management institutions. In the end, the community often chooses to fulfill the obligation to pay zakah by way of distribution directly to the parties who are entitled to receive it.

Mubarok \& Fanani (2014) outline several factors that are thought to influence the low realization of zakah collection in Indonesia. These factors include: people not fully trusting the appointed zakah collection institutions; and there are still many Muslims who do not understand how to calculate zakah or to whom the zakah is entrusted for distribution. Another factor is the weakness of the rules and institutional framework for zakah and the low efficiency and effectiveness of the utilization of zakah funds.

One theory that is often used to understand the way people act is the Theory of Planned Behavior (TPB) which was created by Azjen (1991). Heikal et al. (2014) use TPB to test factors that influence the intention to pay zakah. Azman $\&$ Bidin (2015) have also used TPB and find that intention to pay zakah is influenced by attitude, preferent group, religiosity, and perceived corporate credibility. Abashah et al. (2018) have used TPB and find a significant effect of attitude and subjectivity on zakah-paying behavior. Meanwhile, Tajuddin et al. (2015) find a significant effect of understanding on zakah, and of convenience of facilities, on zakah compliance behavior. Muhammad \& Saad (2015) find a positive and significant effect of moral reasoning and attitude on intention to pay zakah.

This study aims to examine the relationship between knowledge and trust and zakah-paying behavior. TPB is used to understand the factors that influence the intention to pay zakah and the zakah-paying behavior. Structural models have been used to determine the relationship between these variables.

\section{Literature Review and Hypothesis}

\subsection{Theory of Planned Behavior and Zakah-Paying Behavior}

The concept of TPB is very familiar in understanding one's motivation in taking action. It is a development of the theory of reason action (TRA) and was developed by Azjen (1991). TPB is suitable for explaining any behavior that requires planning. Constructs in TPB are attitude, subjective norm, and perceived behavioral control as antensedent variables on intention and behavior variables.

Zakah is viewed from a language perspective is sacred, growing, blessing, and commendable, all used in the Qur'an and the hadith. The growing and sacred meaning is not used for the treasure but also for the soul of the person who gives it. As the word of Allah SWT in the Quran surah at-Taubah (9) verse 103 which means "Take Zakah from some of their wealth, with the zakah you purify and purify them, and pray for them. The prayer of your prayer is to make peace for them. And Allah is Hearing, Knowing. "In addition, according to the term jurisprudence, zakah means a certain amount of duty required by Allah to be handed over to persons entitled in accordance with the provisions set forth in the Qur'an, Hadith, and Ijma.

Khasanah (2016) explains compliance is the motivation of a person, group, or organization to submit to existing rules. Muzaki's compliance in zakah paying means the desire of muzaki to pay the profession of zakah in accordance with Islamic provisions. This is related to religious norms which oblige to pay zakah. Myers in Khasanah (2016) mentions that there are four factors that determine compliance, namely the emotional distance of the victim, closeness, legitimacy of authority, and the effect of freedom from participants' non-compliance.

Zakah is an important instrument in income distribution, especially in the Indonesian Muslim community. The government has issued legislation to improve the quality of zakah funds management in the community. Law Number 36 of 1999 concerning Management of Zakah has been issued by the Government. The law was amended to become Law No. 23 of 2011. In a more operational manner, Government Regulation No. 14 of 2014 concerning Implementation of Law No. 23 of 2011. Law No. 23 of 2011 states the form of zakah management organizations / organizations in Indonesia are BAZ, UPZ, and LAZ. Saf (2015) shows that there are Regional Regulations (Perda or Peraturan Daerah) issued by the Regional Government (Pemda or Pemerintah Daerah) related to optimizing the collection and management of zakah funds. Sidoarjo Regency, Bondowoso Regency and Mojokerto City are regions that have regulations concerning zakah.

\subsection{Effect of Knowledge on Intention to Pay Zakah and Zakah-Paying Behavior}

Knowledge is one of the factors determining the intention of the Muslim community (umma) in paying zakah. 
Rashid (2010) states that proper education is needed to increase people's knowledge and understanding so that they have a strong intention to pay zakah. Finally, the umma will be obedient in paying zakah. According to the TPB perspective, knowledge is an internal factor that will influence one's intention to carry out an action. Saad et al. (2015) also recommend dealing with knowledge as an internal factor that will influence zakah-paying behavior. Syahrullah \& Ulfah (2016) also argue that knowledge is an important factor that influences the zakah-paying behavior.

Huda \& Gofur (2012) demonstrate that knowledge has a significant effect on the intention to pay the professional zakah. Mukhlis \& Beik (2013), Sidiq (2015), Pangestu (2016), Fakhruddin (2016) and Sedjati et al. (2018) also find the same thing: knowledge is a significant predictor of zakah-paying behavior. Haji-Othman et al. (2018) find that the motivation to pay zakah includes knowledge about zakah. In addition, Saad \& Haniffa (2014) state that decisions that influence individuals to pay or not pay zakah are not entirely related to intention. Afridiana et a.l. (2018) obtain different results and find no significant effect on the intention to pay zakah. The research hypotheses developed are as follows:

H1a: Knowledge has a positive and significant effect on Intention to Pay Zakah

H1b: Knowledge has a positive and significant effect on Zakah-Paying Behavior

H1c: Intention to Pay Zakah has a positive and significant effect on Zakah-Paying Behavior.

\subsection{Effect of Trust on Intention to Pay Zakah and Zakah-Paying Behavior}

One of the factors that influence the low realization of zakah collection is trust in the institutions appointed to collect it (Mubarok \& Fanani, 2014). The trust felt by those Muslim members of the community who are obliged to pay zakah (muzakki) is a strong determinant of the intention to pay and paying behavior. If an appointed zakah institution is able to demonstrate professionalism in managing zakah funds, the community will increasingly trust the institution. The community will fulfill the obligation to pay zakah through the appointed collection institution. The same opinion was also expressed by Liana (2018) that trust is a factor that can influence zakah-paying behavior. Bariyah (2010) shows a change in public trust in zakah management institutions because of the lack of information regarding zakah distribution.

Some researchers have shown empirical evidence that trust can influence the zakah-paying behavior including Sidiq (2105), Fakhruddin (2016), Yunus (2016), and Satrio \& Siswantoro (2016). Trust causes the muzakki to feel more comfortable because the zakah management institutions will manage the zakah funds as well as possible.

The research hypotheses developed are as follows:

H2a: Trust has a positive and significant effect on Intention to Pay Zakah

$\mathrm{H} 2 \mathrm{~b}$ : Trust has a positive and significant effect on Zakah-Paying Behavior.

The research framework is shown in Figure 1 below. Knowledge and trust are determinants of intention to pay zakah and obedient zakah-paying behavior. Intention to pay zakah is a mediating variable.

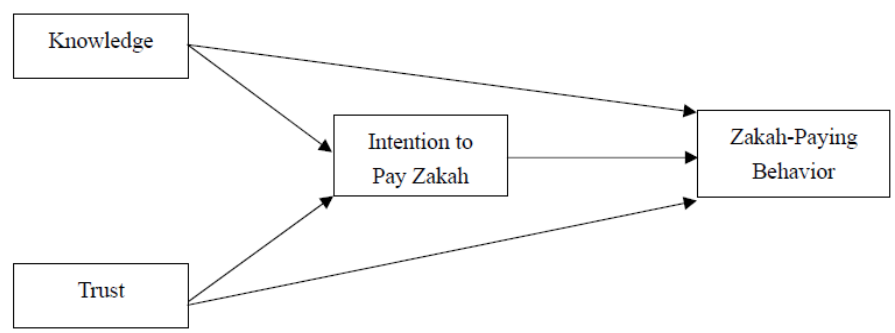

Figure 1. Conceptual framework

\section{Method}

The population in this study is the muzakki working for the Ministry of Religion in the Semarang municipal area who are registered with the National Zakah Collection Agency (Badan Amil Zakah Nasional or BAZNAS). Determination of the sample in this study uses the non-probability sampling technique with a type of purposive sampling. The criteria in taking thr sample are respondents who are employees of the Ministry of Religion Office in 
Semarang and of the Semarang Religious Affairs Office.

The research variables consist of knowledge, trust, intention to pay zakah, and zakah-paying behavior. Knowledge and trust are antecedent variables, while the intention to pay zakah, and zakah-paying behavior are the dependent variables. Zakah-paying behavior is measured using three indicators (namely awareness, obedience, and consistency). Intention to pay zakah is measured using four indicators (namely target, action, situation, and time). Indicators for the measurement of the knowledge variable are knowledge about professional zakah, professional zakah law, and the amount of professional zakah that must be paid. Meanwhile there are seven measurement indicators for the trust variable (namely openness, competency, honesty, integrity, accountability, sharing, and appreciation).

The data collection method used is a questionnaire using a 5-point Likert scale which has been developed based on the opinions of previous researchers. For the Knowledge variable there are 9 statements; the trust variable has 11 statements, and the intention to pay zakah and zakah-paying behavior variables have 4 statements.

The data analysis method used is path analysis. Data are processed using warpPLS software to test the structural relationships between variables. Data analysis is also carried out by describing variables.

\section{Results}

WarpPLS software version 6.0 has been used to analyze the data. The test results show the value of the composite reliability coefficients of the knowledge, trust, intention to pay zakah, and paying behavior zakah variable are 0.716 , $0.762,0.920,0.821$. Meanwhile, the value of Cronbach's alpha coefficients of the knowledge, trust, intention to pay zakah, and zakah-paying behavior variables are $0.564,0.663,0.884$, and 0.707 . Thus, it can be stated that the research instrument has met the requirements in terms of validity and reliability.

The model test results are as follows. The average path coefficient (APC) $=0.307, \mathrm{P}<0.001$. Average R-squared $(\mathrm{ARS})=0.508, \mathrm{P}<0.001$. Average adjusted R-squared (AARS) $=0.500, \mathrm{P}<0.001$. The value $\mathrm{P}$ from APC, ARS, and AARS is less than 0.001 which means the model is fit (i.e. meets the requirements) so hypothesis testing can be continued. Other results show that the average block VIF $(\mathrm{AVIF})=1.761$, acceptable if $<=5$, ideally $<=3.3$. Average full collinearity VIF (AFVIF) $=2.464$, acceptable if $<=5$, ideally $<=3.3$. AVIF and AFVIF values also meet the ideal limit so the model can be declared fit (i.e. meets the requirements).

\subsection{Path Analysis and Hypothesis Testing Results}

Figure 2 shows the results of the path analysis and hypothesis testing. The first model, with intention to pay zakah (IPZ) as the dependent variable, shows that the probability value of the knowledge variable (KNOW) is less than 0.01 with a coefficient of 0.03 . This means that the knowledge variable is proven to have a positive and significant influence on intention to pay zakah. The probability value of the trust variable is less than 0.01 with a coefficient of 0.28 which means that the trust variable has a positive and significant effect on intention to pay zakah. The results of this study show that knowledge has a coefficient greater than trust which means its influence is stronger.

The next result of this study is about zakah-paying behavior as a dependent variable. The probability value of the knowledge variable is less than 0.01 with a coefficient of 0.57 which means that knowledge has a positive and significant effect on zakah-paying behavior. The probability value of the trust variable is less than 0.01 with a coefficient of 0.36 , which means that the trust variable is proven to have a positive and significant effect on the zakah-paying behavior. Meanwhile, the probability value of the intention to pay zakah variable is 0.48 or more than 0.05 and means intention to pay zakah is not proven to have a significant effect on zakah-paying behavior. The results of the study show that knowledge has a coefficient greater than trust which means its influence is stronger.

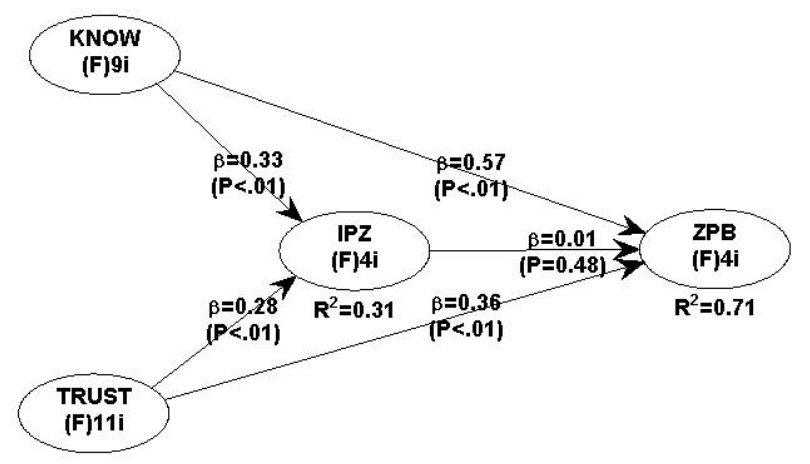

Figure 2. Path analysis 


\section{Discussion}

\subsection{Effect of Knowledge on Intention to Pay Zakah and Zakah-Paying Behavior}

The results show that knowledge is demonstrated as having a positive and significant effect on intention to pay zakah and zakah-paying behavior. The influence is also stronger than the trust variable. This shows that knowledge is very important in influencing someone to intend to pay zakah and to make regular zakah payments. Someone having better knowledge about zakah will increase their intention to pay zakah. And the person will carry out these obligations continuously.

The results of this study are in line with findings of previous researchers who have succeeding in finding that knowledge has a significant effect on intention to pay zakah (Huda \& Gofur, 2012; Muhklis \& Beik, 2013; Sidiq, 2015; Fakhruddin, 2016; Sedjati et al., 2018; Hajj -Othman et al., 2018) and knowledge has a significant effect on zakah-paying behavior (Saad et al., 2015; Syahrullah \& Ulfah, 2016).

Indonesia is a country with a huge potential for zakah funding because the Muslim population is around 200 million people. However, according to BAZNAS (2016) there are gaps that occur between the potential and realization of zakah fund acquisition. This is caused by several things, including the low awareness of muzaki to pay zakah through zakah institutions, the low trust of muzaki towards zakah institutions, and the behavior of muzaki who are still oriented in the short term, decentralized and interpersonal. Semarang City is one of the big cities that has very large Muslim citizens. Yuskar (2013) found that the management of zakah that is more professional can increase the compulsory understanding of zakah to fulfill the obligation to pay zakah at BAZ or LAZ. This understanding is based on sufficient knowledge about zakah. The Semarang city government together with the zakah management organization can organize various forms of activities to increase muzaki's knowledge about zakah and its management.

\subsection{Effect of Trust on Intention to Pay Zakah and Zakah-Paying Behavior}

A person's belief in something will affect his or her intention to act. The results show that public trust in appointed zakah-collection institutions has been demonstrated to have a significant effect on his or her intention to pay zakah. This trust also influences the community to continue to pay zakah regularly. The trust of the muzakki community must be maintained properly by the appointed zakah-collection institutions. The results of this study are in line with the opinion of Liana (2018) which states that trust is a factor that can influence the zakah-paying behavior. Sidiq (2105), Fakhruddin (2016), Yunus (2016), and Satrio \& Siswantoro (2016) find empirical evidence that trust can be a significant predictor of zakah-paying behavior.

Services for muzaki and mustahiq by zakah management organizations are very important. Service quality will greatly influence public trust in the performance of zakah management institutions. Zakah management organizations in Indonesia and in Semarang City still need to improve the quality of their services. Rodiyah \& Muhammad (2015) showed the results of the study that the level of satisfaction of muzaki and mustahiq for zakah management institutions in Yogyakarta was quite good, which was $76.44 \%$. However, the quality of the organization is categorized as poor and still does not show maximum service performance. These findings indicate that the zakah management organization, especially in the city of Semarang, should have improved the services provided to muzaki and mustahiq. Service quality will affect the level of trust in the organization. This trust will increase interest in paying zakah through zakah management organizations.

\subsection{Effect of Intention to Pay Zakah on Zakah-Paying Behavior}

TPB explains that people's behavior is influenced by their intentions. That is to say, someone will do something if he or she intends to do it. This study has not succeeded in demonstrating the effect of intention to pay zakah on zakah-paying behavior. This is probably due to the payment of zakah being an obligation for a Muslim. Meaning, whether or not there is intention, zakah payments must still be made.

Awareness of paying zakah through zakah management organizations (BAZ or LAZ) is a behavior that must be a habit of Muslim communities, including in Semarang City. Paying zakah is an obligation to purify assets and income earned. Paying zakah through BAZ or LAZ is the best choice, so that zakah funds can be distributed more evenly and professionally. Management organizations must improve their performance so that they can manage zakah well, by carrying out their activities based on the principles of good governance.

\section{Conclusion}

Intention to pay zakah and zakah-paying behavior can be understood in terms of the knowledge and trust of zakah payers (muzakki). Knowledge has a stronger influence than trust. The knowledge of muzakki must be improved so 
that the intention to pay zakah will increase. The appointed zakah-collection institutions can organize activities to disseminate information or provide education for muzakki to increase their knowledge about zakah.

\section{Acknowledgements}

We thanks to Faculty of Economics Universitas Negeri Semarang for research funding. We thanks to editor of International Journal of Financial Research for publishing the article.

\section{References}

Abashah, A., Samah, I. H. A., Saraih, U. M., Rashid, I. M. A., Ramlan, N., \& Radzi, W. N. S. W. M. (2018). The Impact of Attitude and Subjective Norms towards Zakah Compliance Behavior in Malaysia. International Journal of Engineering \& Technology, 7(3.21), 171-174.

Afridiana, N., Rohman Ab., \& Ningsih, K.S. (2018, November 15-16). Kidz Jaman Now Effect: How Millennials' Opinion Leader in Social Media Can Influence Their Followers' Intention to Pay Zakah. Paper to be presented at International Conference of Zakah, Universitas Gadjah Mada, Yogyakarta, Indonesia.

Ajzen, I. (1991). The theory of planned behavior. Organizational Behavior and Human Decision Processes, 50, 179-211. https://doi.org/10.1016/0749-5978(91)90020-T

Azman, F. M. N., \& Bidin, Z. (2015). Factors Influencing Zakah Compliance Behavior on Saving. International Journal of Business and Social Research, 5(1), 118-128.

Bakar, N. B. A., \& Rashid, H. M. A. (2010). Motivations of Paying Zakah on Income: Evidence from Malaysia. International Journal of Economics and Finance, 2(3), 76-84.

Bariyah, N. O. N. (2010). Kontekstualisasi Total Quality Management Dalam Lembaga Pengelola Zakah Untuk Pemberdayaan Ekonomi Masyarakat (Prinsip dan Praktik). Universitas Islam Negeri Syarif Hidayatullah Jakarta.

Baznas, P. (2016). Outlook Zakah Indonesia 2017. Jakarta: Puskas Baznas.

Canggih, C., Fikriyah, K., \& Yasin, A. (2017). Potensi dan Dan Realisasi Dana Zakah Indonesia. Al-Uqud: Journal of Islamic Economics, 1, 14-26. https://doi.org/10.26740/al-uqud.v1n1.p14-26

Fakhruddin, M. (2016). Analisis Pengaruh Tingkat Pengetahuan Zakah, Tingkat Religiusitas, Tingkat Pendapatan, Dan Tingkat Kepercayaan Kepada BAZNAS Terhadap Minat Membayar Zakah Profesi Pada Pekerja (Studi Kasus Pekerja Di DKI Jakarta). Universitas Diponegoro.

Haji-Othman, Y., Yusuff, M. S. S., \& Latib, M. F. A. (2018). Motivations for Paying Income Zakah among UniSHAMS'Employees. Seminar Pengurusan Kewangan Islam dan Zakah, Pada 11 Oktober 2018 bertempat di Dewan Tuanku Permaisuri Hajjah Haminah, UniSHAMS.

Heikal, M., Khaddafi, M., \& Falahuddin. (2014). The Intention to Pay Zakah Commercial: An Application of Revised Theory of Planned Behavior. Journal of Economics and Behavioral Studies, 6(9), 727-734.

Huda, N., \& Gofur, A. (2012). Analisis Intensi Muzakkî dalam Membayar Zakah Profesi. Al-Iqtishad, IV(2), 217-240.

Khasanah, U. (2016). Pengaruh Religiusitas, Pengetahuan Zakah, Altruisme, Pendapatan, Akuntabilitas Keuangan, Aksesibilitas, Terhadap Kepatuhan Membayar Zakah Profesi. Universitas Negeri Semarang.

Liana, P. N. (2018). A Preliminary Study on Norms and Motivations towards Zakah and Income Tax Payment by Muslim Tax Payer. International Academic Journal of Accounting and Financial Management, 5(3), 118-123.

Mubarok, A., \& Fanani, B. (2014). Penghimpunan Dana Zakah Nasional (Potensi, Realisasi dan Peran Penting Organisasi Pengelola Zakah). Permana, V(2), 7-16.

Muhammad, S. A., \& Saad, R. A. (2015, December 16-17). Moderating effect of attitude toward zakah payment on the relationship between moral reasoning and intention to pay zakah. 3rd Global Conference on Business and Social Studies 2015, Kuala Lumpur Malaysia.

Mukhlis, A., \& Beik, I. S. (2013). Analisis Faktor-faktor yang Memengaruhi Tingkat Kepatuhan Membayar Zakah: Studi Kasus Kabupaten Bogor. Jurnal Al-Muzara'ah, I(1), 83-106. https://doi.org/10.29244/jam.1.1.83-106

Pangestu, I. (2016). Analisis Dalam Faktor-Faktor Yang Mempengaruhi Motivasi Muzakki Membayar Zakah Di Lembaga Amil Zakah Kota Semarang. Universitas Negeri Semarang.

Rodiyah, S., \& Muhammad, A. (2015). Analisis Six Sigma: Upaya Peningkatan Kinerja Layanan zakat (Studi Kasus 
Di Badan Amil Zakat Nasional Kota Yogyakarta). Jurnal MD, Edisi Januari-Juni, 53-74.

Saad, R. A., Wahab, M. S. A., \& Samsudin, M. A. M. (2015, December 16-17). Factors Influencing Business Zakah Compliance Behavior among Moslem Businessmen in Malaysia; a Research Model. 3rd Global Conference on Business and Social Studies 2015, Kuala Lumpur Malaysia.

Saf, Mhd. A. (2015). Efektivitas Pelaksanaan Perda Pengelolaan Zakat di Kota Mojokerto dan Kabupaten Sidoarjo. AL-DAULAH: Jurnal Hukum Dan Perundangan Islam, 5(2), 312-332. https://doi.org/10.15642/ad.2015.5.2.312-332

Satrio, E., \& Siswantoro, D. (2016). Analisis Faktor Pendapatan, Kepercayaan Dan Religiusitas Dalam Mempengaruhi Minat Muzakki Untuk Membayar Zakah Penghasilan Melalui Lembaga Amil Zakah. Simposium Nasional Akuntansi XIX, 1(4), 308-315.

Sedjati, D. P., \& Basri, Y. Z. (2018). Analysis of Factors Affecting the Payment of Zakah in Special Capital Region (DKI) of Jakarta. The International Journal of Business \& Management Indonesia, 6(1), 92-100.

Sidiq, H. A. (2015). Pengaruh Pengetahuan Zakah, Tingkat Pendapatan, Religiusitas Dan Kepercayaan Terhadap Organisasi Pengelola Zakah Terhadap Minat Membayar Zakah Pada Lembaga Amil Zakah: Studi Kasus Terhadap Muzakki di Fakultas Agama Islam dan Fakultas Ekonomi dan Bisnis. Universitas Muhammadiyah.

Syahrullah, \& Ulfah, M. (2016). Response of Indonesian Academicians Toward Factors Influencing the Payment of Zakah on Employment Income. Research on Humanities and Social Sciences, 6(10), 87-94.

Tajuddin, T. S., Azman, A. S., \& Shamsuddin, N. (2015, June). Compliance Behaviour Of Zakah on Salary Income Among Muslim Youth in Klang Valley. E-Proceeding of the International Conference on Social Science Research, 8\&9. Meliá Hotel Kuala Lumpur, Malaysia.

Yunus, M. (2016). Analisis Pengaruh Kepercayaan, Religiusitas dan Kontribusi Terhadap Minat Pedagang Mengeluarkan Zakah Di Baitul Mal (Studi Kasus Pada Pedagang Pasar Los Lhokseumawe). At-Tawassuth, 1(1), 95-124.

Yuskar. (2013). Kajian Efektivigas Pengelolaan Zakat sebagai Suatu Usaha untuk Pemberdayaan Masyarakat dan Pengentasan Kemiskinan di Kota Padang. Jurnal Kajian Akuntansi dan Auditing, 8(1), 1-21. 